\title{
The Effect of Corporate Governance, Corporate Responsibility, and Stock Liquidity on Financial Performance
}

\author{
Yulia Rohaza, Muslim A.Djalil, Mulia Saputra* \\ Faculty of Economics and Business, University Syiah Kuala, Indonesia
}

*Corresponding Author: Mulia Saputra, Faculty of Economics and Business, University Syiah Kuala, Indonesia

\begin{abstract}
The purpose of this study is to examine and analyze the effect of corporate governance, corporate responsibility, and stock liquidity on financial performance in Indonesia. To examine and analyze the effect of corporate governance on financial performance in Indonesia. To examine and analyze the effect of corporate responsibility on financial performance in Indonesia. To test and analyze the effect of stock liquidity on financial performance in Indonesia. Data analysis in this study uses multiple linear regression which aims to test and analyze, both jointly and partially the effect of corporate governance, corporate responsibility, and stock liquidity on financial performance in Indonesia, which is processed using the SPSS program (Statistical Package For Social Science) 22.The results of the study show that corporate governance, corporate responsibility, and stock liquidity have a positive effect on financial performance in Indonesia. Or in other words it's going well.
\end{abstract}

Keywords: coorporate governance, corporate responsibility, stock liquidity and financial performance

\section{INTRODUCTION}

Profitability is the ability of a company to fulfill obligations for persons with funds that show the value or prospects of the company in the future. Therefore, investors will only invest their funds in companies that have a good reputation. A company that has a good reputation is a company that is able to increase company profits and provide constant dividends to shareholders. The higher the profit achieved by the company, the higher the company's share price.

But not all companies experience profits, such as the aviation industry in the country that is facing a difficult situation. From expensive avtur costs, making tickets is expensive. As a result, the level of airline occupation is also never full. Moreover, the low season at the beginning of the year was allegedly getting heavier than the previous year. Meanwhile, AirAsia Indonesia recorded a less encouraging performance throughout 2018. AirAsia recorded a loss (before tax) of Rp 998 billion in 2018. (www.cnnindonesia.com)

The airline Lion Air Group is also known to be requesting a delay in the payment of airport services to PT Angkasa Pura I (Persero) or AP-I. The bills postponed by the payment include room and land rent, aircraft parking fees, landing fees, garbarata, check in counters to baggage handling systems. The application was motivated by financial pressures in the airline business. One of them was because of the income that was not achieved due to the low selling price of the ticket, and not comparable with the increase in operational costs. (www.tirto.id)

The loss was also experienced by state-owned companies, where as many as 24 companies under the auspices of the Ministry of State-Owned Enterprises (BUMN) suffered losses in the second quarter of 2019. The loss of 24 SOEs in the first semester of 2017 amounted to $\mathrm{Rp} 5.852$ trillion. Following are the developments in the profitability of state-owned companies listed on the Indonesia Stock Exchange.

The emergence of corporate governance was motivated by a number of major scandals that occurred in companies both in the United Kingdom and the United States in the 1980s due to actions that tended to be greedy and concerned with the objectives of certain parties. This is inseparable from the conflict of interest between personal freedom and collective responsibility or the common interest of the organization, which makes it a trigger for the need for corporate governance.

In the framework of decision making, investors need information from both inside and outside the 
capital market. Outside the capital market can be a corporate governance rating index conducted by a company. Currently many corporate governance resources are being investigated in companies which are then developed by research institutions One of the information that can be used in Indonesia is corporate governance perception index (CGPI).

CGPI improves its quality from year to year as indicated by an increase in survey participants and the addition of aspects to their assessment criteria. The ranking of corporate governance indexes can provide benefits to the management of the company and potential investors.

CGPI rating can be used by the management of evaluation materials on corporate governance that has been implemented. For prospective investors, CGPI is used as information to find out the corporate governance that has been implemented. A good rating describes management has managed the company well so that it can improve the company's image for investors The level of corporate governance is an important issue to oversee the company in carrying out its performance practices (Low and Poon, 2008). This CGPI ranking index is conducted once every year. CGPI's results are to give appreciation and recognition to companies that have implemented good corporate governance as three ranks, which are "Highly Trusted", "Trusted", and "Reliable enough".

The next factor that affects profitability is Corporate responsibility. Corporate responsibility (CR) is a corporate responsibility activity for stakeholders by giving attention to social aspects and income. The importance of implementing Corporate Responsibility is now increasingly recognized by various companies as one of the business strategies. In accordance with the opinion expressed by Amanti (2012), by implementing Corporate responsibility, companies can create a good image for the company so as to generate positive evaluations from consumers who are able to increase their loyalty to the products produced by the company. Through social responsibility (CSR) activities, also known as triple bottom line, which is in addition to pursuing profit (profit), the company also pays attention to and is involved in fulfilling people's welfare (people) and contributing actively in preserving the environment (planet). These three elements then synergize to form the concept of sustainable development.

The next factor that affects profitability is stock liquidity. Stock liquidity is the ease of shares owned by someone to be converted back into cash through a market mechanism (Koetin, 2002). To attract buyers and sellers to participate in this, the capital market must be liquid and efficient. In other words, it is very profitable for investors if the shares are liquid because with high stock liquidity, investors have a great opportunity to get returns compared to stocks with low liquidity.

Stock liquidity is clearly seen from the trading activity of a stock. Trading activity can be seen from how many investors trade on a stock. The higher the trading volume, the greater the liquidity of the stock. A large volume of stock trading indicates that the stock is actively traded and used for see the capital market reaction to information. The greater the supply and demand for shares, the greater the trading volume and the higher the level of liquidity of the shares traded.

\section{LiTERATURE REVIEW}

\subsection{Stock Liquidity}

Stock liquidity according to the Indonesia Stock Exchange (General Information on Capital Markets, Stock Exchange) in Mulyana (2011) liquidity is a smoothness that shows the level of ease in disbursing investment capital. In general, Sharpe et al. (1999) defines liquidity as the ability of investors to sell assets or assets they have without having to make concessions or allowances for assets. Liquidity can also be viewed from several aspects such as the level of trading volume and frequency of trading.

Stock size is a measure of the number of transactions in a stock market in a given period. So the more liquid the stock, the higher the frequency of stock transactions (Mulyana 2011). The frequency of trading greatly affects the number of shares outstanding and indirectly affects the volume of stock trading this is because of the high investor interest in the stock. Shares that have a high level of trading volume are possible to have a high level of liquidity and provide a higher probability of getting a rate of return.

According to Wijayanto (2005) for investors, the level of stock liquidity can be described from the trading volume of a stock. The greater the volume of transactions, the faster and easier a stock is traded so that changes in stocks to cash are faster. 
In the context of relations with securities, Brown (2009: 296) states that the determinants of market liquidity with respect to securities are highly reflected in market trade data and the most important factor of liquidity is the amount of money traded on shares.

Good corporate governance shows management's ability to manage the company. Companies with good governance certainly will not hesitate to open information as widely as possible to the public, they need accurate information.

CSA Research Institute Senior Analyst Reza Priyada said that the selection of shares by investors considered many aspects. Good corporate governance is only a small part of that aspect. There are other aspects such as the growth of financial performance, liquidity, buying and selling volumes (bid offer), sentiment, news related to global economic conditions, to the development of the issuer's business sector which is more considered by investors before deciding which stock to choose (investment. cash).

\section{RESEARCH METHOD}

\subsection{Data Analysis Equipment}

Equipment Data analysis using is done through the SPSS program (Statistical Product and Service Solution) 2.2. The analytical method used is multiple linear regression which aims to test and analyze, both simultaneously (together) and partially to determine whether the independent variables (corporate governance, corporate responsibility, and stock liquidity) have a significant or no effect on the dependent variable (profitability). Processed by the SPSS program (Statistical Package For Social Science) 22.

To answer the existing problems and test the hypotheses that have been determined and to obtain a comprehensive picture to find out how much influence the independent variables on the dependent variable. Then the analysis method used is a multiple regression analysis technique based on Ordinary Least Squere (OLS).

\section{FINDING AND DISCUSSION}

\subsection{The Effect of CGPI, CSR, and Stock Liquidity on Financial Performance}

The results of the tests together (simultaneous) show that CGPI, CSR, and stock liquidity have a joint effect on financial performance. This shows that financial performance is determined jointly by the background of education, CSR, and stock liquidity. The coefficient of determination (R2) of 0.546 means that CGPI, CSR, and stock liquidity are able to explain variations of the financial performance variable by $54.6 \%$ while the remaining $45.4 \%$ is explained by other variables not included in this research variable.

\subsection{The Effect of CGPI on Financial Performance}

The test results show a significance value of 0.017 . The determination of the hypothesis states that if the value of sig is below alpha $5 \%$ or 0.05 then $\mathrm{H} 0$ is accepted, meaning that CGPI has an effect on financial performance. The coefficient value is 0.572 , meaning that the CGPI has a positive effect on financial performance. The greater the CGPI it will improve the company's financial performance.

\subsection{The Effect of CSR on Financial Performance}

The test results showed a significance value of 0.001 . The determination of the hypothesis states that if the significance value is below alpha $5 \%$ or 0.05 then Ha is accepted, meaning that CSR has an effect on financial performance. The coefficient value is 16,943, meaning that CSR has a positive effect on financial performance. The greater the CSR, the better the financial performance of the company.

\subsection{The Effect of Stock Liquidity on Financial Performance}

The test results show a significance value of 0.021 . The determination of the hypothesis states that if the significance value is below alpha 5\% then $\mathrm{H} 0$ is accepted, meaning stock liquidity has an effect on financial performance. The coefficient value is 2.098 , meaning that stock liquidity has a positive effect on financial performance. The greater the stock liquidity, the better the company's financial performance.

\section{Conclusions}

- CGPI, CSR, and liquidity of shares have a joint effect on financial performance of companies listed on the Stock Exchange in 2011-2017. 
The Effect of Corporate Governance, Corporate Responsibility, and Stock Liquidity on Financial Performance

- CGPI influences the financial performance of companies listed on the IDX in 2011-2017.

- CSR affects the financial performance of companies listed on the Stock Exchange in 2011-2017.

- Stock liquidity has an effect on financial performance of companies listed on the Stock Exchange in 2011-2017.

\section{RECOMMENDATIONS}

- The next researcher can use several other types of company sectors on the IDX to develop the results of the current research.

- Researchers can then use proxies other than in this study such as company size and capital adequacy as a measure in future studies.

\section{REFERENCES}

[1] Agoes, Sukrino. 2011. Auditing Edisi 4. Jakarta: Salemba Empat

[2] Ang, Robert. 1997. Buku Pintar Pasar Modal Indonesia. Jakarta:Media Staff Indonesia.

[3] Chung, K. H., Elder, J., \& Kim, J. C. 2010.Corporate governance and liquidity.Journal of Financial and Quantitative Analysis, 45, 265-291.

[4] Fahmi, Irham. 2013. Analisis Laporan Keuangan. Bandung: Alfabeta.

[5] Fahmi, Irham. 2015. Pengantar Manajemen Keuangan Teori dan Soal Jawaban. Bandung: Alfabeta.

[6] Ghozali, Imam. 2013. Aplikasi Analisis Multivariate Dengan Program SPSS. Semarang : BP UNDIP.

[7] Hadi, Nor. 2011. Corporate Social Responsibility. Yogyakarta : Graha Ilmu.

[8] Hery, Achmad 2014.Analysis of the effect of Capital, Operational Efficiency, Credit Risk and Profitability to the Implementation of Banking Intermediation Functions.Academic Research International. Vol. 5, No. 4.

[9] Hery. 2016. Analisis Laporan Keuangan. Jakarta: Penerbit PT Grasindo.

[10] Kasmir. 2012. Analisis Laporan Keuangan. PT.Raja Grafindo Persada, Jakarta

[11] Kasmir. 2013. Analisis Laporan Keuangan. Rajawali Pers : Jakarta.

[12] Kasmir. 2014. Analisis Laporan Keuangan. Edisi Satu. Cetakan Ketujuh. Jakarta: PT Raja Grafindo Persada.

[13] Kholis, Nur. 2017. Pengaruh Corporate Responsibility terhadap Kinerja Keuangan. Iqtisidha.Vol.7 No.2.

[14] Nursalam. 2013. Metodologi Penelitian Ilmu Keperawatan: Pendekatan Praktis :Jakarta : SalembaMedika.

[15] Patricia, Jessica. 2017. Pengaruh Good Corporate Governance terhadap Kinerja Keuangan. Jurnal Ilmiah Mahasiswa Universitas Surabaya.Vol.6 No.2.

[16] Rizal, Arif. 2016. Pengaruh Corporate Responsibility dan Corporate Governance terhadap Kinerja Keuangan. Prosiding Akuntansi.Vol.3 No.2.

[17] Rusdianto, Ujang. 2013. CSR Communication a Framework for PR Practitionsers. Yogyakarta: Graha Ilmu.

[18] Sekaran, Uma dan Roger Bougie. 2016. Research Methods for Business. Edisi Ketujuh. United Kingdom: John Wiley \& Sons.

[19] Sugiyono. 2012. Metode Penelitian Administrasi. Cetakan Ke-20.Penerbit Alfabeta. Bandung.

[20] Sunariyah.2013. Pengantar Pengetahuan Pasar Modal (Edisi 6).Penerbit : UPPSTIM YKPN, Yogyakarta.

[21] Widarjono, Agus. 2009. Ekonometrika Pengantar dan Aplikasinya.Edisi Ketiga. EKONISIA.Yogyakarta.

[22] Wijayanto, Andi. 2005. Pengaruh Nilai Tukar Rupiah, Tingkat Suku Bunga Deposito dan Volume Perdagangan Saham terhadap Harga Saham, Jurnal Keuangan dan Perbankan, no. 3.

[23] Wiranti, Sri. 2017. Pengaruh Likuiditas Saham dan Harga Saham terhadap Kinerja Keuangan.Jurnal Akuntansi dan Bisnis. Vol.3 No.2.

Citation: Yulia Rohaza, Muslim A.Djalil, Mulia Saputra. " The Effect of Corporate Governance, Corporate Responsibility, and Stock Liquidity on Financial Performance" International Journal of Managerial Studies and Research (IJMSR), vol 7, no.9, 2019, pp. 17-20. doi: http://dx.doi.org/10.20431/2349-0349.0709003.

Copyright: () 2019 Authors. This is an open-access article distributed under the terms of the Creative Commons Attribution License, which permits unrestricted use, distribution, and reproduction in any medium, provided the original author and source are credited. 